\title{
92. The Climatic Conditions of the Eocene Woodwardia Zone, Ishikari Coalfield, Hokkaido, with Description of Ficus eowightiana Endo, n. sp.
}

\author{
By Seido Endo \\ (Comm. by Hisakatsu YABE, M.J.A., June 12, 1964)
}

In the southern (Yubari) division of the Ishikari coalfield, the Palaeogene coal-bearing Ishikari Group ${ }^{1)}$ consists of the following five formations, in descending order:

$$
\text { Poronai formation (Eocene) }
$$$$
\text { - Unconformity - }
$$

1. Ikushunbetsu coal-bearing formation

2. Wakkanappe formation

$$
\text { - Unconformity?- }
$$

3. Yubari coal-bearing formation

2. Horokabetsu formation

1. Noborikawa coal-bearing formation

$$
\text { - Unconformity - }
$$

Hakobuchi formation (Upper Cretaceous)

Of them, the Ikushunbetsu formation, especially its lower part (Woodwardia zone) is very rich in plant fossils, and the writer could discriminate about 62 species listed below:

Table I. Fossil plants from the Woodwardia zone

\author{
Equisetum ezoensis Endo \\ Dennstaedtia americana Knowlton \\ Onoclea hebraidica Gardner \\ Osmunda regalis L. var.? \\ Woodwardia japonica Sw. var. \\ eocenica Endo (new var.) \\ Cephalotaxus yubariensis Endo \\ Glyptostrobus europaeus Heer \\ Sequoia disticha Heer \\ Sequoia Langsdorfi Brongniart \\ Taxodium distichum miocenum Heer \\ Geonomites yubariensis Endo \\ Musophyllum complicatum Lesquereux \\ Acer Arcticum Heer \\ Alnus Kefersteinii (Goeppert) \\ Alnus paleojaponica Endo \\ Betula Brongniarti Ettingshausen \\ Betula paleomaximowicziana Endo \\ Broussonetia Imaii Endo \\ Carpinus Shimokawarai Endo \\ Carpinus Takaoi Endo
}

Cercidiphyllum arcticum Brown

Cercidiphyllum elongatum Brown

Cercidiphyllum paleojaponicum Endo

Cercis hokkaidoensis Endo

Celastrus typica MacGinitie

Celastrus borealis Heer

Corylus Fasteri Ward

Diospyros protokaki Endo

Dombeyopsis yubariensis Endo

Dryophyllum yubariensis Endo

Dryophyllum sp.

Fagus Antipofii Abich

Fagus sp.

Ficus eowightiana Endo

Ficus ezoensis Endo

Ficus columbioides Endo

Ficus occidentalis Lesquereux

Ficus planicostata Lesquereux

Ficus planifolioides Endo

Ficus tennesseensis Lesquereux

Ficus tiliaefolia Heer 


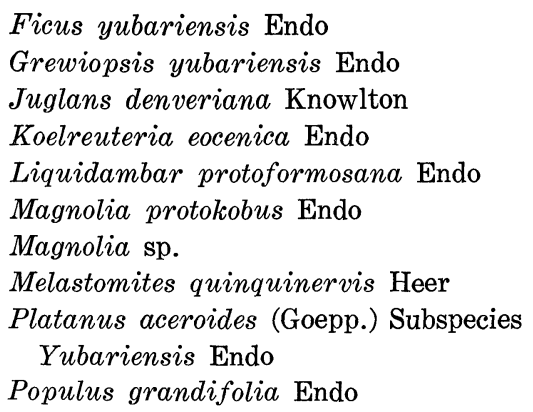

\author{
Ptelea eocenica Endo \\ Pyrus yubariensis Endo \\ Rhamnus protoutilis Endo \\ Sassafras alaskanum Hollick \\ Sassafras yubariensis Endo \\ Styrzx protobassia Endo \\ Tilia eojaponica Endo \\ Ulmus nipponica Endo \\ Viburnum Nordenskiöldi Heer \\ Viburnum paleowightii Endo \\ Viburnum protoerosum Endo
}

The greater part of the plant remains are impressions of treeleaves of the genera same with those now growing in the tropical, temperate and frigid zones of East Asia, and the present fossil flora bears an aspect in its constitution closely related to the recent one of central Kyushu.

In the southern part of the Kumamoto city, central Kyushu, there exist many beautiful forests of desiduous trees and ferns growing luxuliantly, and the recent flora of this tract has lately been studied by Kanjiro Mayehara in detail (Table II); it is somewhat similar to and reminds one strongly of the ancient flora of the Woodwardia zone.

Table II. Selected list of plants living in the southern tract of Kumamoto

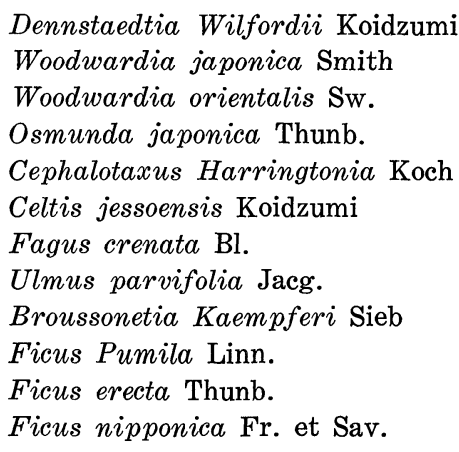

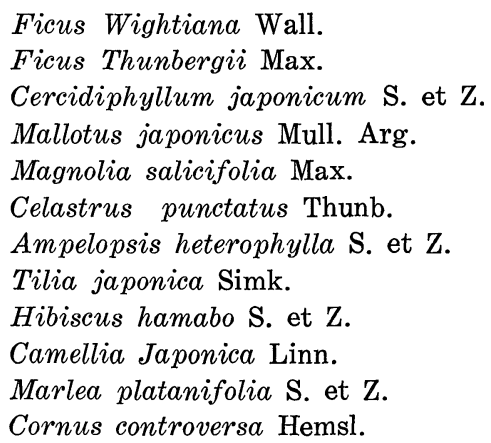

(Besides, there are many species of the genera, Salix, Carpinus, Quercus, prunus and of the families, Lauraceae, Aceraceae, Caprifoliaceae, etc.)

The most conspicuous species of the fossil flora is Woodwardia japonica Sw. var. eocenica Endo, n. var., ${ }^{1)}$ since its remains are most abundant. It belongs to the group of Woodwardia virginica and is an ally of $W$. japonica Sw. now thriving only in the warm-temperate zone of southern Japan (Ryukyu Islands, Kyushu, southern Shikoku), beside Formosa. In general, Woodwardia is a member of warm temperate flora with a narrow geographical range. $W$. orientalis $\mathrm{Sm}$. is another most common fern of southern, warm temperate zone of Japan; the northern limit of its distribution is the sea cliffs of 
the Paciffic coast at Iwama, near the town Ueda, southern Fukushima Prefecture. This locality is a rare warm place, exceptionally warm even in winter, and $W$. orientalis grows there luxuriantly in large colonies.

Broussonetia Imaii is another characteristic species of the Woodwardia zone; it is very similar to $B$. Kaempferi Sieb. living in the warm temperate zone of Japan.

Ficus eowightiana Endo resembles so closely F. wightiana Wall. of the present day, particularly in the characteristic impression of its peduncular base, as if the former being the direct ancestor of the latter.

There are now about 700 species of the genus Ficus in the world, and a few of them are growing in southern Japan. A. G. Nathorst ${ }^{9)}$ once distinguished three climatic zones in Japan referring to the plantdistribution, namely, the Ficus wightiana-, Pinus thunbergi-, and Fagus crenata zones, the first occupying the southernmost part of the Japanese Islands, the second northern Kyushu, Shikoku and southern Honshu, and the third northern Honshu and southern Hokkaido. His Ficus wightiana zone just corresponds to the warm temperate zone. Ficus eowightiana, like $F$. wightiana, may serve as an indicator of the warm temperate climate under which the fossil flora of the Woodwardia zone once existed.

Next, the leaf margin of dicotyledonous trees seems to depend much on climatic conditions. In general, the percentage of the number of species of trees with entire leaf margin, to the total number of them increases rapidly from the frigid forest zone, through the temperate and warm temperate forest zones to the tropical forest zone, just in the opposite sense with the trees having duplicately serrate leaf margin. This percentage hardly amounts to 8 in northern Hokkaido of the frigid forest zone, while it attains 12 in southern Hokkaido and 46 in the southernmost Kyushu around Kagoshima of the warm temperate forest zone.

The annexed Table III shows the percentage of the species of dicotyledonous trees with entire and double-serrate leaf margin respectively to the total number of them at various districts in Japan

Table III

Micronesia $^{4)}$ and Philippines ${ }^{13)}$

Ryugamitsu near Kagoshima city $^{8}$

Southern Kumamoto Prefecture ${ }^{7}$

Sendai city, Miyagi Prefecture ${ }^{12)}$

Near Sapporo city, Hokkaido ${ }^{5)}$

Tokyo University forest, Chichibu, Kwanto Mts. 15

$\begin{array}{cc}\text { Entire } & \text { Double-serrate } \\ 90 \% & 0 \% \\ 46 & 2 \\ 33 & 12 \\ 21 & 14 \\ 12 & 27 \\ 15 & 38\end{array}$


and those of the Micronesia and the Philippines for comparison.

The present writer could discriminate about 50 species of dicotyledonous plants in the abundant fossil leaves obtained from the Woodwardia zone, and noticed that $35 \%$ of them possessed leaves of entire margin and $14 \%$ leaves of double-serrate margin. The percentages approach closely those of the modern forests of southern Kumamoto.

Plant-growth much depends on climatological factors, especially temperature and humidity; the climate in the life-time of the fossil flora of the Woodwardia zone may approximately inferred from that of the Kumamoto district of the present day. The temperature and humidity, 1933-1950, recorded at Kumamoto, are quoted below from "Climate of Japan" 1958. ${ }^{10}$

\begin{tabular}{|c|c|c|c|c|c|c|c|c|c|c|c|c|c|}
\hline & Jan. & Feb. & Mar. & Apr. & May & June & July & Aug. & Sept. & Oct. & Nov. & Dec & Year \\
\hline Mean & 4.3 & 5.3 & 8.9 & 14.1 & 18.5 & 22.3 & 26.4 & 27.0 & 23.2 & 17.1 & 11.7 & 5.8 & 15.5 \\
\hline Max. & 9.9 & 11.1 & 15.1 & 20.7 & 24.9 & 27.6 & 31.3 & 32.6 & 28.9 & 23.8 & 18.3 & 12.7 & 21.4 \\
\hline Min. & -0.7 & 0.1 & 2.9 & 7.7 & 12.7 & 17.5 & 22.5 & 22.7 & 18.6 & 11.3 & 5.8 & 1.4 & 10.2 \\
\hline $\begin{array}{r}\text { Relat. Humidity } \\
(\%)\end{array}$ & 75 & 73 & & 73 & 75 & 78 & 81 & 78 & 79 & 76 & 77 & 77 & 76 \\
\hline $\begin{array}{r}\text { Rainfall amount } \\
(\mathrm{mm})\end{array}$ & 49 & 74 & 114 & 148 & 161 & 321 & 312 & 165 & 174 & 91 & 75 & 73 & 1757 \\
\hline
\end{tabular}

It is almost certain that the fossil flora of the Woodwardia zone enjoyed a warm temperate climate during life.

Description

Ficus eowightiana Endo, n. sp.

Figs. 1-3

Description: Leaves ovate lanceolate, $14 \pm \mathrm{cm}$ long, $6.5 \pm \mathrm{cm}$ wide. Midrib straight and stout, with two acrodromatic basal secondaries; other secondaries in $6 \pm$ pairs, curving upwards and looping along nearmargin, with veinlets between Tertiaries and quaternaries forming net-works with the others. Petiole long $4 \pm \mathrm{cm}$. Branchlets with many characteristic impressions or concave peduncle-base, $0.4 \pm \mathrm{mm}$ in diameter, with trace of 7 or more vascular bundles. Texture thick and coriaceous.

Remarks: The fossil leaves are quite similar to those of existing Ficus wightiana Wall., which is the most characteristic species of Japan growing in the warm temperate region of southern Kyushu and southern Shikoku. The former are larger than the latter and have the secondary veins less in number. The branchlets have many impressions of peduncle-base, which are quite identical with those of the living species. $F$. eowightiana may be the remote ancester of $F$. wightiana. 


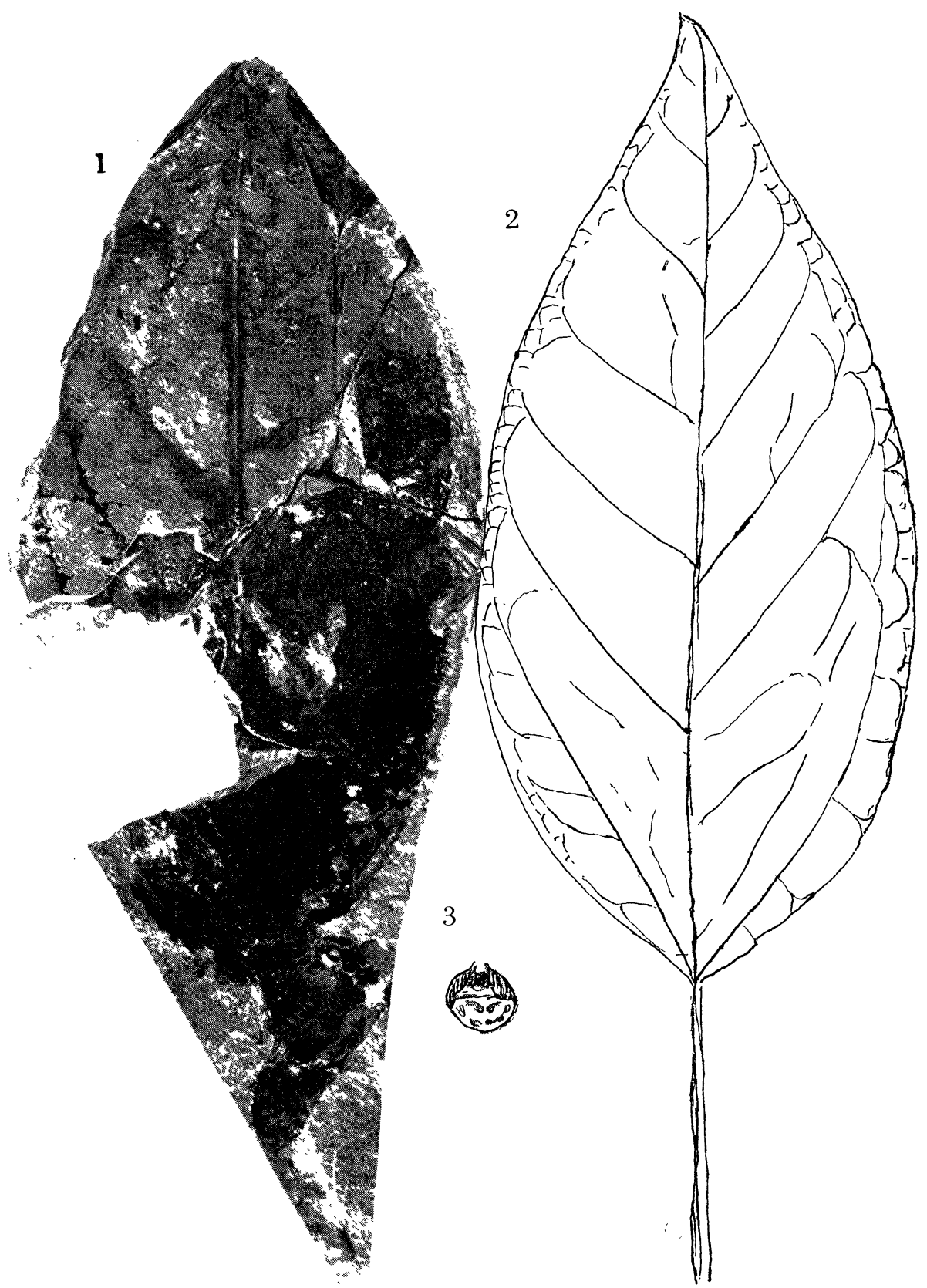

Fig. 1. Ficus eowightiana Endo $\times$ ca. 1. Fig. 2. Ficus eowightiana Endo $\times$ ca. 1. Restored from Fig. 1. Fig. 3. Peduncular base impression from Ficus eowightiana Endo $\times$ ca. 3 .

Locality: Kakuda coal-field, Kuriyama-machi, Yubari-gori, Hokkaido. 
Localities: Kakuda coal-mines, Kuriyama-machi, Yubari-gun, Hokkaido.

Geological occurrence: Woodwardia zone of the Ikushunbetsu formation, Ishikari Group; Eocene.

\section{References}

1) S. Endo (1962): On the Eocene plants from the Woodwardia formation of the Ishikari Group. Trans. Proc. Paleont. Soc. Japan, N. S., no. 45, pp. 206-208, pl. 31 .

2) E. Dorf (1960): Climatic changes of the past and present. American Scientist, 48(3).

3) T. Inokuma (1941): Preliminary notes on the Ligneous Plants indigenous in the "Chichibu" University Forest and its adjacent districts. (Bull. of University Forest, no. 14).

4) R. Kanehira (1933): Flora Micronesica.

5) K. Miyabe and Y. Kudo (1921-1931): Icones of the Essential Forest Trees of Hokkaido vols. I-III.

6) M. Kusaka and Y. Kobayasi (1953): A list of plants, spontaneous in Asakawa Experiment Forest Pteridophyta and Spermatophyta. Bull. of the Government Forest Experiment Station, no. 63.

7) K. Mayebara (1931): Enumeratio Plantarum in Provincia Higo Australe Sponte Nascentium.

8) K. Naido (1953): Flora in Ryugamitsu (near Kagoshima city) (manuscript).

9) Mathorst A. G. (1888): Zur Fossilen Flora Japans (Paleont. Abhandl., Bd. 4).

10) K. Wadachi (1958): Climate of Japan.

11) Reid, C., and Reid, E. (1915): The Pliocene Floras of the Dutch-Prussian Border. Mitteil. Bohr. Nisderlander. 6.

12) Faculty of Science, Tohoku Univ. (1960): Index Plantarum Vascularium quae in Horto Botanico Aobaiamano.

13) Whiteford H. N. (1911): The principal forest trees (The Forest of the Philippines, Part II). Depart. of the Interior Bureau of Forestry, Bull., no. 10. 